\title{
DETERMINATION OF THE EROSIVE SUSCEPTIBILITY FROM A HYDROGRAPHIC BASIN USING FREE AVAILABLE GEO-TECHNOLOGY
}

\author{
João Lucas Alves da SILVA ${ }^{1}$ \\ Vinícius de Oliveira RIBEIRO² \\ Leonardo Lima dos SANTOS
}

\begin{abstract}
Erosion is a natural process resulting from the interaction of rainfall and soil, which is enhanced by factors such as inadequate management of soil and removal of vegetation cover. This causes an excessive production of sediments, generating phenomena such as eutrophication and silting of watercourses. The Universal Soil Loss Equation (USLE), allows to estimate erosion under different land use/land conditions as well as under variable slope, slope length, soil types and rainfall. It allows the elaboration of thematic maps and it is an important research tool to analyze the erosive process. When applied with open and free available geo-technologies, it dramatically reduces the costs of performing the study. This study aimed to map and analyze qualitatively the erosive susceptibility of the Laranja Doce hydrographic basin, located in the city of Dourados - Mato Grosso do Sul State in the year of 2016, applying the USLE and geo-technologies that are available free on Internet. The average annual soil losses ranging 0-33 ton/ha/ year were obtained. Most of the area was classified with Low to Moderate Erosion since its erosive rate was lower than 15 ton/ha/year. It was observed that the spatial distribution of erosion is influenced especially by the soil cover and relief features described by the $\mathrm{CP}$ and LS factors, respectively.
\end{abstract}

Key words: Erosion. Free geo-technologies. QGIS.

\footnotetext{
1 Environmental Engineering Student - Universidade Estadual de Mato Grosso do Sul - UEMS. Cidade Universitária de Dourados - Rodovia Itahum, Km 12, s/n - Jardim Aeroporto, 79804-970, Dourados - MS. E-mail: jlalves@protonmail.com

2 Researcher and Professor of Environmental Engineering -Universidade Estadual de Mato Grosso do Sul - UEMS. Cidade Universitária de Dourados - Rodovia Itahum, Km 12, s/n - Jardim Aeroporto, 79804-970, Dourados - MS. E-mail: viniciusoribeiro@yahoo.com.br

3 Environmental Engineering Student - Universidade Estadual de Mato Grosso do Sul - UEMS. Cidade Universitária de Dourados - Rodovia Itahum, Km 12, s/n - Jardim Aeroporto, 79804-970, Dourados - MS. E-mail: leo.limaengambiental@gmail.com
} 


\section{Resumo}

\section{Determinação da susceptibilidade erosiva de bacia hidrográfica utilizando geotecnologias livres e gratuitas}

A erosão hídrica é um processo natural que decorre da interação das chuvas e do solo, a qual é potencializada por fatores como o manejo inadequado deste solo e retirada da cobertura vegetal, o que causa a produção excessiva de sedimentos, gerando fenômenos como a eutrofização dos corpos d'água e também o assoreamento destes. A Equação Universal de Perda do Solo (USLE), permite estimar a erosão, sob variadas condições de uso e cobertura do solo, declividade, comprimento de rampa, tipos de solo e chuva, e por meio da elaboração de mapas temáticos representa importante instrumento de investigação sobre o processo erosivo. Quando aplicada por meio de geotecnologias livres e gratuitas, reduz drasticamente os gastos de execução do estudo. Este trabalho teve por objetivo mapear e analisar qualitativamente a susceptibilidade erosiva dos solos da bacia hidrográfica do córrego Laranja Doce, localizada no município de Dourados - MS no ano de 2016, por meio da aplicação da Equação Universal de Perda do Solo - USLE e das geotecnologias disponíveis de forma gratuita na rede. Obteve-se perdas médias anuais de solo variando de 0 a 33 ton/ha.ano. A maior parte da área é classificada com erosão nula a moderada por possuir taxa erosiva menor que 15 ton/ha.ano. Observou-se que a distribuição espacial da erosão é influenciada principalmente pela cobertura vegetal do solo e das características do relevo demonstradas através dos fatores CP e LS respectivamente.

Palavras-chave: Erosão. USLE. QGIS.

\section{INTRODUCTION}

Water erosion is a natural process resulting from the interaction of rainfall and soil. This interaction is potentiated by factors such as the inadequate management of this soil and removal of vegetation cover, which causes excessive sediment production, generating phenomena such as eutrophication and siltation of water bodies (SPATTI JUNIOR, 2011). These processes eliminate or reduce the flow of fountains, modify the flow of the drainage in river channels and decrease the useful life of reservoirs.

In addition to release of particles that will clog soil pores, the impact of rain drops on the unprotected soil causing its thickening, resulting in the sealing of its surface and, therefore reducing the water infiltration capacity (SILVA et al., 1995).

The Universal Soil Loss Equation (USLE) (WISCHMEIER; SMITH, 1978) is an empirical model to estimate the average annual loss of soil by laminar erosion, which represents an important investigative tool to study the erosion process. The characteristics and properties of properties of the environmental factors are responsible for soil losses, allowing partitioning of the landscape into instability levels, thus permitting effective actions of planning and optimization of natural resources (WISCHMEIER AND SMITH, 1978).

Geographic Information Systems facilitated the application of USLE at various scales, as they are particularly useful for handling heterogeneous data such as topographic charts, soil charts, land cover, land use, meteorological data, etc. Although they are of different nature and scale, these charts supplemented with other information allow the quantitative estimation of the eroded soil, per year, caused by the rainwater flow along the slopes. 
Paranhos Filho et al. (2015) modeled USLE in a GIS environment using open and free geo-technologies to analyze qualitatively the soil erosion susceptibility in a municipality in Mato Grosso do Sul State. These authors concluded that GIS are a tool of great efficiency to characterize areas susceptible to laminar erosion, allowing the quick and easy acquisition, manipulation and integration of data.

\section{OBJECTIVE}

The objective of this study is to map and qualitatively analyze the erosive susceptibility of the soil from the Laranja Doce hydrographic basin, located in the city of Dourados, Mato Grosso do Sul State, using the Universal Soil Loss Equation (USLE) and the free geo-technologies available at Internet.

\section{MATERIALS AND METHODS}

\section{Area under study}

The area under study is the Laranja Doce micro basin, delimited by latitude $\mathrm{S}$ $21^{\circ} 55^{\prime}-22^{\circ} 16^{\prime}$ and longitude WGr 54${ }^{\circ} 28^{\prime}-54^{\circ} 52^{\prime}$, extending over an area of about $715 \mathrm{~km}^{2}$, with a length of $57.49 \mathrm{~km}$ in NE - SW direction involving two cities: Dourados and Douradina (SOARES FILHO, 2006).

The micro basin is located within the Paraná hydrographic system, the Ivinhema River sub-basin and the Bilhante River basin. About $80 \%$ of its area is located in the city of Dourados and the other $20 \%$ in the city of Douradina, both in Mato Grosso do Sul.

Among the main streams that flow across the city, only Laranja Doce crosses the north of it, in the W-E direction, presenting the largest volume of water among all these streams and the longest length in the urban perimeter. The stream has its springs in the city of Dourados / Mato Grosso do Sul State and its mouth flows into the Brilhante River. Its location is shown in Figure 1. 


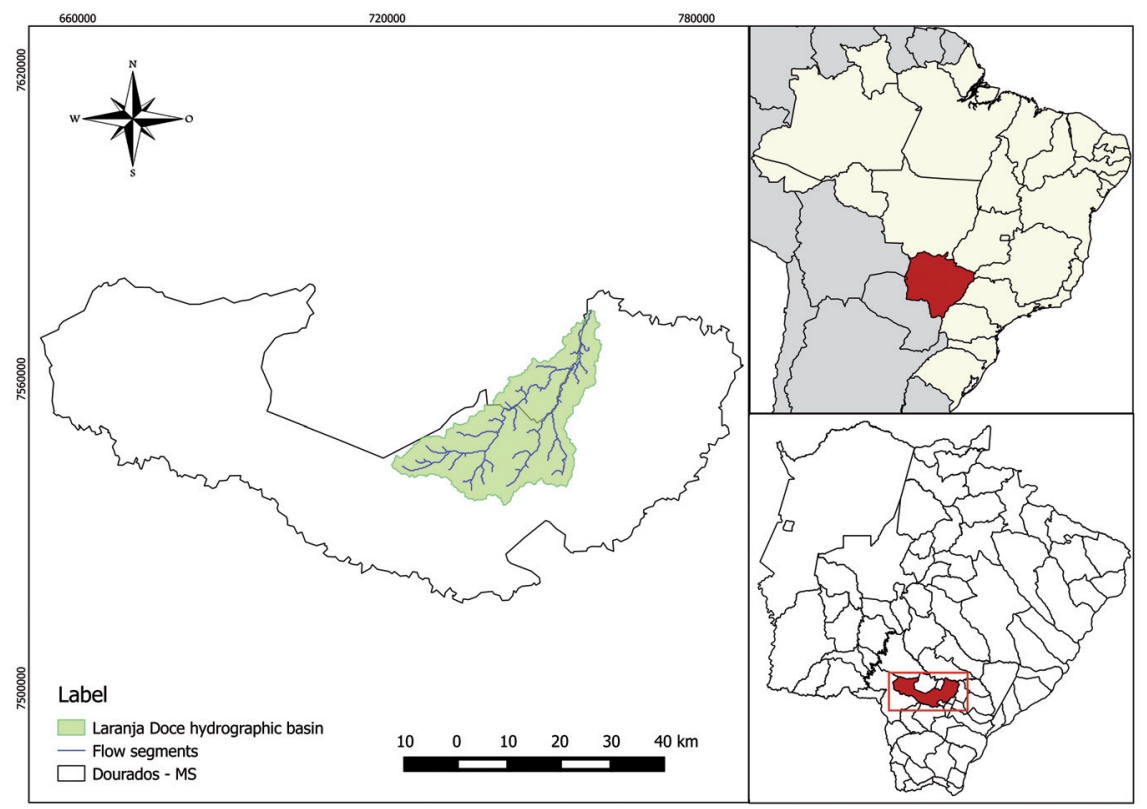

Figure 1 - Location of Laranja Doce hydrographic basin, in Dourados/Mato Grosso do Sul State, modified (CORRÊA, 2015)

USLE

The Universal Soil Loss Equation (USLE) (WISCHMEIER; SMITH, 1978) is an empirical model used to promote the average annual soil loss for sheet erosion, considering six independent factors:

$$
A=\text { R.K.(L.S).C.P }
$$

Whereas: $\mathrm{A}=$ average annual soil loss per unit of area (tons/acre/year); $\mathrm{R}=$ rain erosivity; $\mathrm{K}=$ soil erodibility; $\mathrm{L}=$ slope length; $\mathrm{S}=$ slope declivity; $\mathrm{C}=$ use and management of the soil and $\mathrm{P}=$ conservationist practices.

\section{Data Collection}

For the estimation of the sheet erosion by water, two primary sources were used: the SRTM (Shuttle Radar Topography Mission) digital surface model (DSM) (USGS, 2000) with $30 \mathrm{~m}$ spatial resolution and a LANDSAT 8 image dated from June $17^{\text {th }}, 2016$ with $30 \mathrm{~m}$ resolution, obtained from Earth Explorer website (Earth Explorer, 2016). Vector files (points, lines and polygons) in shapefile format (ESRI, 1997) were also used to represent the highways, the political administrative boundary of Mato Grosso do Sul State, Dourados city and the soil chart (at 1:250,000) of Mato Grosso do Sul State, acquired from Instituto Brasileiro de Geografia e Estatística (IBGE, 2016) and Instituto do Meio Ambiente de Mato Grosso do Sul (IMASUL), respectively.

For all phases of this study, the free software QGIS 2.8.8 (QGIS Development Team, 2015) was used. 


\section{Data processing}

The methodology used followed five main phase, namely:

\section{Obtainment of the Topographic Factor (LS)}

After inserting the SRTM (USGS, 2000) into QGIS 2.8.8 (QGIS DEVELOPMENT TEAM, 2015), the Slope, aspect, curvature tool of the SAGA GIS complement was used to obtain a map corresponding to inclination angle $(\theta)$. Subsequently, using the Raster Calculator tool, the map of factor $\beta$ was calculated with Equation (5). Using the same tool at equation (4), the factor $m$ was obtained. The factor $\lambda$ - Slope Length was with the r.watershed tool of the GRASS complement. Hence, it was possible to consider equation (3) to obtain the factor $\mathrm{L}$. The $\mathrm{S}$ factor was calculated with equations (6) and (7) of the Raster Calculator tool. Finally, the maps of factors L and S were multiplied, and thus the Topographic Factor map of the hydrographic basin - LS was obtained.

$$
\begin{gathered}
\text { LS }=\text { L.S } \\
L=\left(\frac{\lambda}{22.13}\right)^{m} \\
m=\frac{\beta}{1+\beta} \\
\beta=\frac{\operatorname{sen} \theta}{\left[3 \cdot(\operatorname{sen} \theta)^{0.8}+0.56\right]} \\
S=10.8 \cdot \operatorname{sen} \theta+0.03 \text { if } \theta<9 \% \\
S=16.8 \cdot \operatorname{sen} \theta-0.50 \text { if } \theta \geq 9 \%
\end{gathered}
$$

Where: $\lambda$ - Slope Length; $m$ - exponent of the Length-Declivity variation; $\beta$ - factor that varies according to the slope declivity and $\theta$ - inclination angle. McCool et al. (1989).

\section{Obtainment of the Land Use and Vegetation Cover Map}

The land use and vegetation cover thematic map was created based on the supervised classification of the LANDSAT 8 image, taken on June 17 $7^{\text {th }}, 2016$ (EARTH EXPLORER, 2016) using the open and free software QGIS 2.8.8 (QGIS DEVELOPMENT TEAM, 2015) and the Semi-automatic Classification Plugin (SCP), a complement that allows the semi-automatic or supervised classification of images pixel by pixel. Using SCP it is possible to create very fast sample areas, called ROIs (Regions of Interest), which are saved in a shapefile format (ESRI, 1997). Four categories of vegetation cover were established: Dense vegetation (Cerrado), Bare soil, Wet areas and Medium to low size vegetation. After determining the areas of interest, the spectral signatures were automatically calculated, creating the vegetation cover thematic map of the hydrographic basin. 


\section{Obtainment of the Rain Erosivity Map - Factor (R)}

The $\mathrm{R}$ factor from USLE was obtained based on the rain erosivity chart of Mato Grosso do Sul State (MS), developed by Oliveira et al. (2012) according to data obtained from three pluviographic stations located in the cities Dourados, Coxim and Campo Grande, and also the precipitation data available from the Hydrological Information System of ANA - Agencia Nacional das Águas (Hidroweb) from 109 pluviometric stations located in Mato Grosso do Sul.

\section{Obtainment of the Soil Erodibility Map - Factor (K)}

To obtain this factor, the Map of Soils of Mato Grosso do Sul provided by the Environmental Institute of Mato Grosso do Sul (IMASUL) was used in 1:250000 scale, in shapefile format (ESRI, 1997), which was inserted into the QGIS 2.8.8 software (QGIS DEVELOPMENT TEAM, 2015) and trimmed according to the boundary of the hydrographic basin considered.

The nomenclature of soil classification was updated according to the Brazilian Soil Classification System (EMBRAPA, 2013) and the $\mathrm{K}$ values attributed to each soil classification were those ones adopted by Paranhos Filho (2000) (Table1). The K values were inserted into the attribute table according to its respective soil groups. Afterwards the shapefile was transformed into raster format with $30 \mathrm{~m}^{2}$, so it could be used in the USLE equation.

\section{Table 1 - K factor for each soil classification of the hydrographic basin}

\begin{tabular}{cccc} 
Symbol & Previous rating & EMBRAPA, 2013 & K Factor (ton.ha.h/ha. MJ mm) \\
\hline HGP & Glei Pouco Húmico & Gleissolo Háplico & 0,001 \\
\hline LR & Latossolo Roxo & Latossolo Vermelho & 0,012 \\
\hline
\end{tabular}

Obtainment of the Map on Use, Management and Conservationist Practices - Factor $(C P)$

The $\mathrm{C}$ and $\mathrm{P}$ factors from USLE were integrated, generating only one map. According to Stein et al. (1987) it is only necessary to work with these factors (C and P) separately if the purpose of the study is to define more appropriate forms of agricultural production. However, if the focus is on soil loss caused by erosion, the variables $C$ and $P$ are interrelated in such a way that they should be analyzed together. Consequently, it is observed that the distribution of CP factors in the study area is directly related to the vegetation cover of the hydrographic basin.

Thus, for each classification on use and vegetation cover, a CP value was determined according to those suggested by Stein et al. (1987) and Oliveira (2012) (Table 2). Afterwards the map of the CP factor was generated in raster format, with 30 $x 30 \mathrm{~m}$ pixel, to be compared with other USLE factors.

Table 2 - CP values for each land use classification (STEIN ET AL.,1987 E OLIVEIRA, 2012)

\begin{tabular}{cc}
\hline Class & CP Factor \\
\hline Dense vegetation & 0,0007 \\
\hline Bare soil & 1 \\
\hline Medium to low vegetation & 0,25 \\
\hline Wetlands & 0 \\
\hline
\end{tabular}


Integration of the USLE factors

After completing the steps to obtain the USLE component factors, the tool "Raster Calculator" of the free and open software QGIS 2.8.8 (QGIS DEVELOPMENT TEAM, 2015) was used to perform the map algebra. From the integration of the equation factors a map of the soil loss estimate by laminar water erosion was created, which is the USLE factor $A$.

\section{RESULTS AND DISCUSSION}

\section{LS Factor}

The map obtained for the LS Factor, which represents the Topographic Potential of Sheet Water Erosion (PARANHOS FILHO, 2000), presents values between 0 and 0.65 . It is observed that there is a predominance of values between 0 and 0.30 , with great frequency of values close to zero (Figure 2). Thus it can be inferred that most of the area under study has low surface runoff rates, which impairs the sheet water erosion.

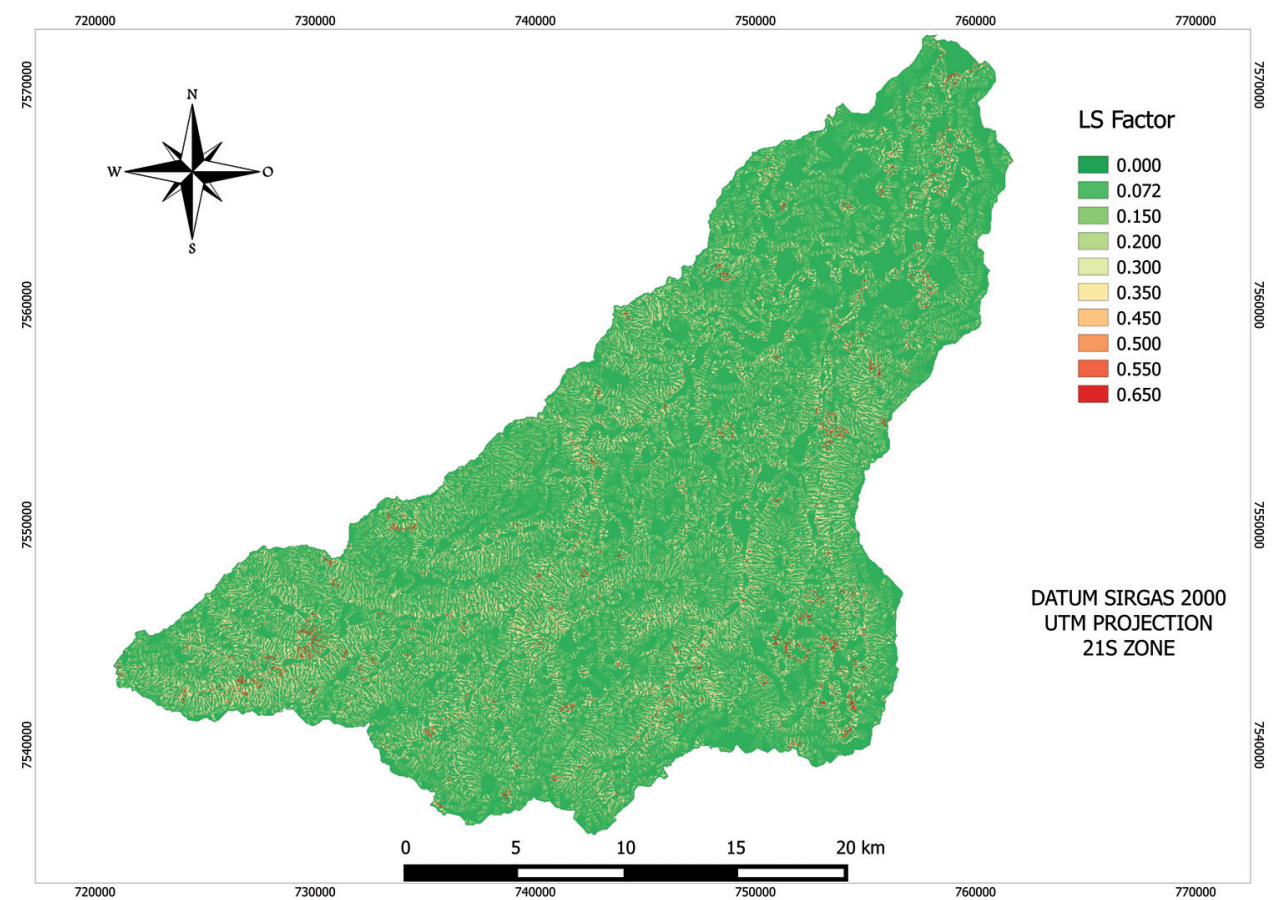

Figure 2 - Chart of the Topographic Factor of the Laranja Doce hydrographic basin - LS Factor 


\section{K Factor}

The soils map of the river basin with the $\mathrm{K}$ values was assigned according to Paranhos Filho (2000) (Figure 3). It can be observed that the entire hydrographic basin area presents Red Latosols, according to the Brazilian Soil Classification System (EMBRAPA, 2013). Latosols are very fertile, and due to that they are widely used for farming activities.

According to Paranhos Filho (2000), despite the good resistance to erosion due to good physical characteristics, Red Latosols require adequate conservation treatments according to the slope and the types of use. A small portion of the basin is composed by Histosols, which presents a low susceptibility to erosion, as they are subject to frequent flooding.

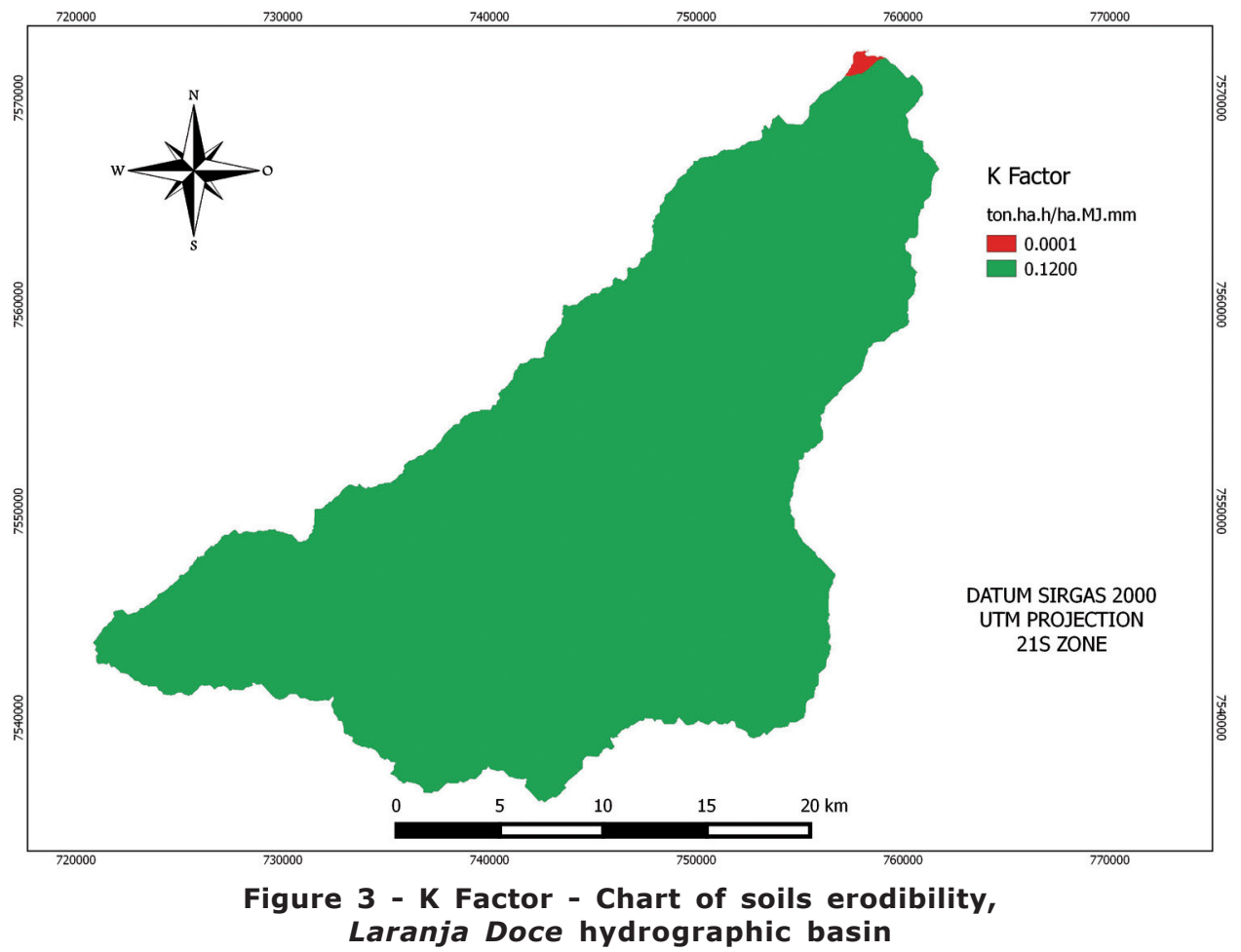

\section{R Factor}

According to the R-Factor map (Figure 4) obtained, the maximum and minimum values for the area under study are 8506.03 and $8701.72 \mathrm{MJ} . \mathrm{mm} / \mathrm{ha} / \mathrm{year}$, respectively. The whole area has an erosivity classified by Santos (2008) as high, in other words, R $>7000$ MJ.mm / ha/year, which may favor the increase of sheet water erosion rates. These values can be explained by the location of the hydrographic basin, where intense rainfall occurs often at different periods of the year. 


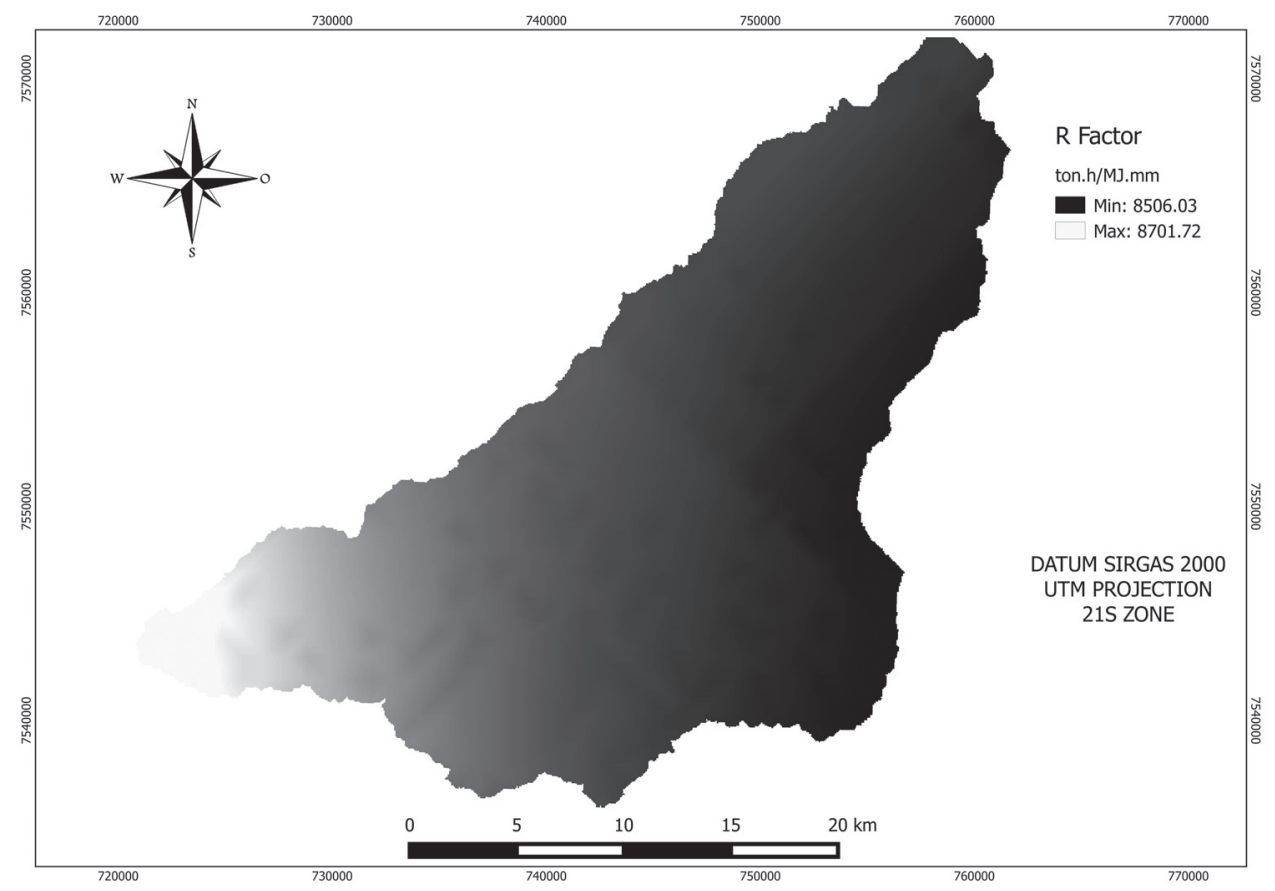

Figure 4 - Chart of the rainfall erosivity in the Laranja Doce hydrographic basin - $\mathbf{R}$ Factor

\section{Plant Cover and CP Factor}

The maps of vegetation cover and its integration with the $\mathrm{CP}$ values, proposed by Stein et al. (1987) and Oliveira (2012) are shown in Figures 5 and 6 respectively. Observing the $\mathrm{CP}$ values and ignoring the humid areas where the value is zero, there are sections where the vegetation is denser and it presents lower CP values. This is due to the ability of the vegetation to protect the soil against the erosive effects of rainfall, either by preventing the direct impact of the drops, avoiding the effect of sprinkling, or by reducing the surface runoff beneath the soil surface (VALENTIN, 2008). Following this perspective, the highest values are present in areas where there is little or no vegetation, such as regions where there is bare soil, and a great susceptibility to erosion. 


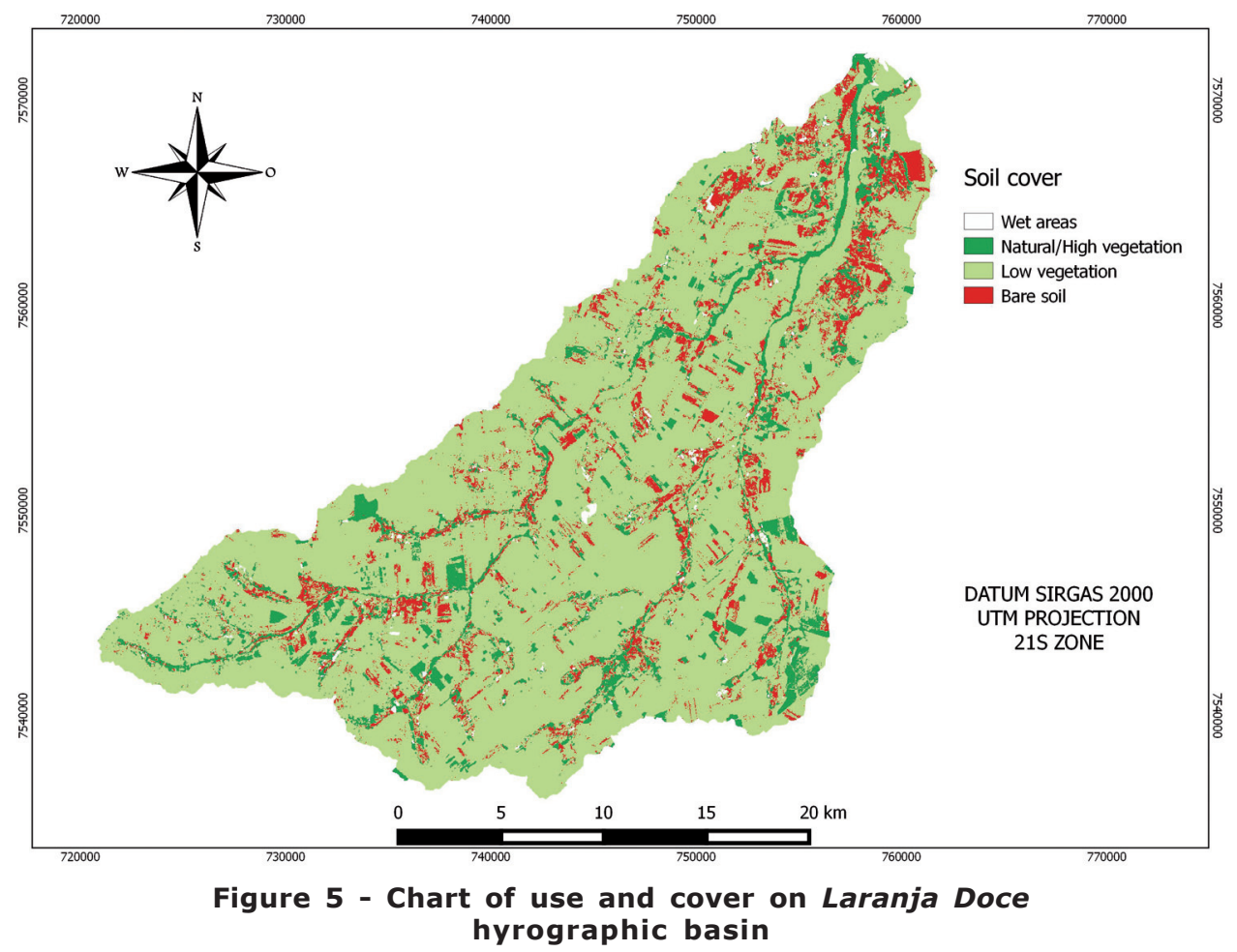




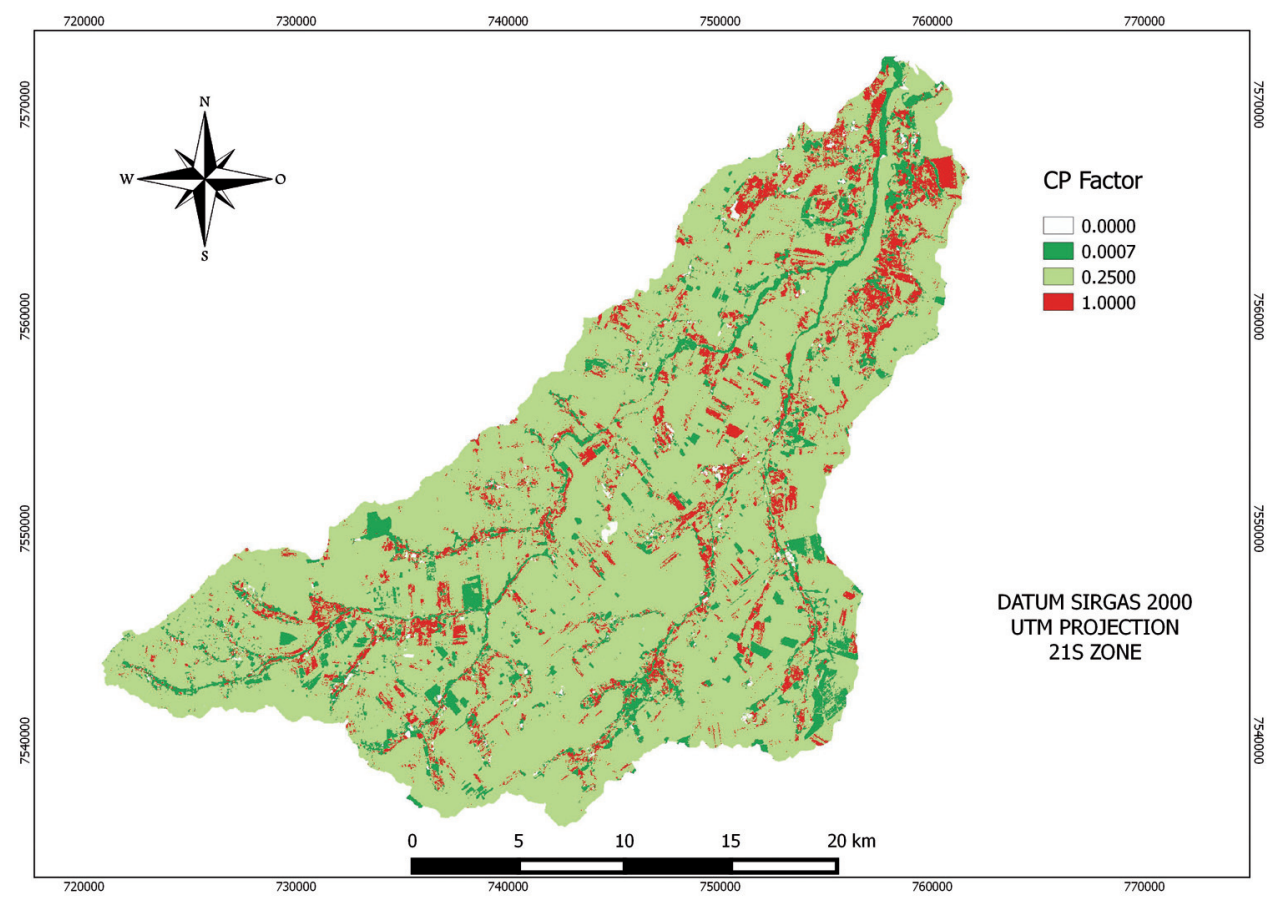

Figure 6 - Chart of use and soil cover and conservation practices on Laranja Doce hydrographic basin

\section{A Factor - current erosion}

From the map algebra, a soil map of loss in tons per year hectare was obtained - A Factor (Figure 7). It should be emphasized as a consequence of the mathematical limitation from the USLE model and the methods used in this work, that the values obtained should not be considered quantitatively, but rather for a qualitative analysis related to potentially erodible areas of the watershed studied (STEIN et al., 1987).

Soil loss values range from 0 to 33 ton/ha / year. When analyzing the map of $A$ factor along with the maps of other factors, it can be inferred that the distribution of annual mean erosion values is mainly associated to soil cover (CP factor) and slope (LS factor), and that there is a lower representativeness of $\mathrm{K}$ and $\mathrm{R}$ factors. Regarding the CP factor, there is the class Wetlands, which leads to zero, and most areas of low slope (LS factor) also lead to low loss of soil values with a predominance of numbers smaller than three. It is important to highlight the regions closest to the water bodies, in other words, the riparian forests, where the influence of natural vegetation on the protection of the soil against laminar water erosion is clearly observed.

In addition to the $\mathrm{CP}$ Factor, there are several sections near the water courses where there is bare soil $(C P=1)$. Consequently these places are those ones which present the highest soil loss values, followed by those where the LS Factor tends to higher values contributing to higher losses even in areas with considerable vegetation cover. In contrast, large sections with dense vegetation $(C P=0.0007)$ and where 
there are extensive slopes, the soil losses are below 3 tons / ha/year. The entire area under study did not show high values of sheet erosion by water, because the soil losses vary between 0 and 33, which according to Carvalho (2008) represents an annual average index of soil loss.

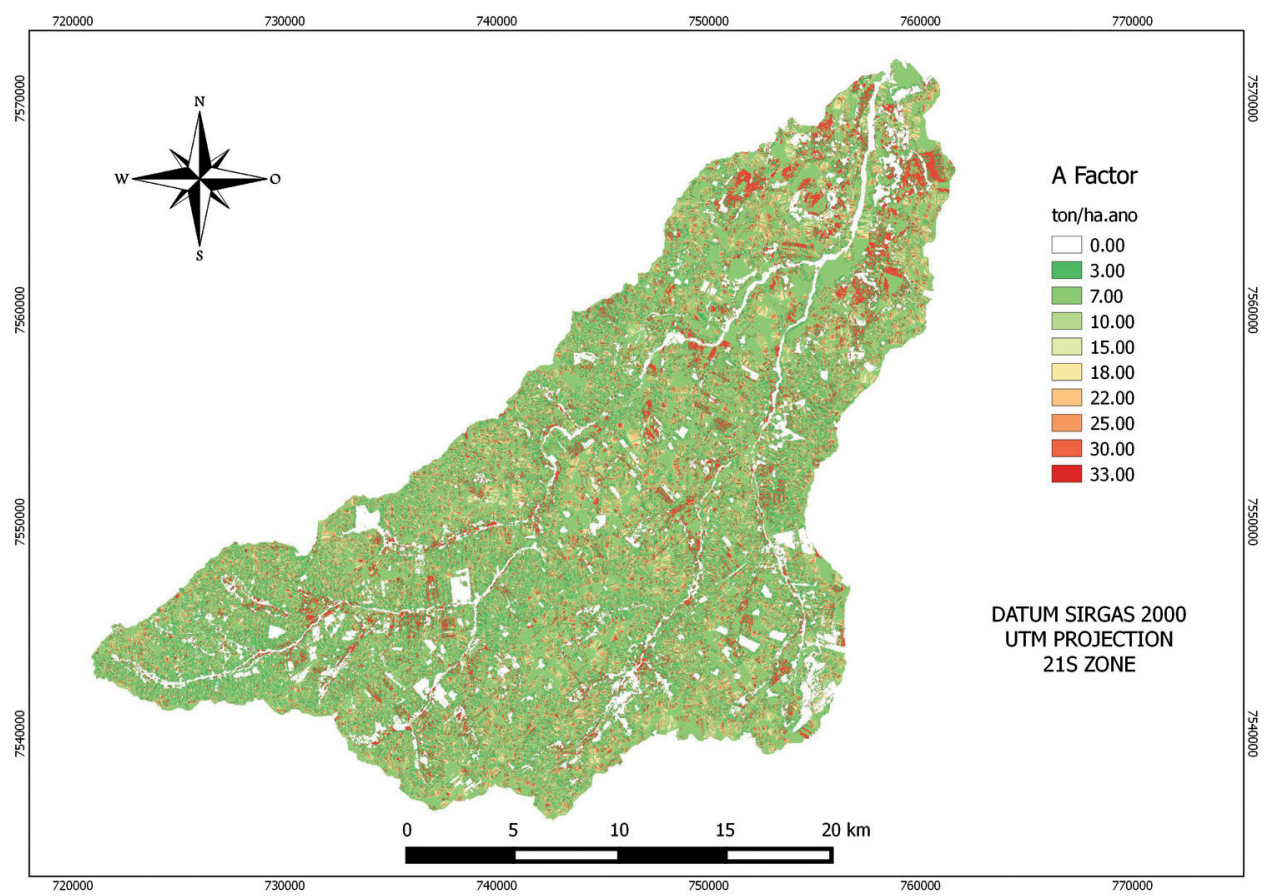

Figure 7 - Chart of the spatial distribution of annual soil loss in the Laranja Doce hydrographic basin - A Factor, 2016

\section{CONCLUSIONS AND SUGGESTIONS}

- Mathematical models of erosion prediction can be considered appropriate tools for the qualitative study of the parameters related to the water erosion process. This helps to make decisions on soil use.

- In spite of its limitations in quantitative aspects, when used on large areas, USLE allows to identify those areas with pronounced soil loss as a consequence of actual occupation.

- The use of SRTM data to obtain the USLE topography factor is a practical and viable alternative, minimizing the costs of work and time of execution;

- The open and free software used was satisfactory and suitable for the purposes of the work, highlighting the advantage that it is of easy access and available free for all users.

- Although this work was not made in the Pantanal, the methodology presented can be applied in certain plateau areas and its surroundings. 


\section{REFERENCES}

CARVAlho, N.O. 2008. Hidrossedimentologia Prática. Rio de Janeiro: CPRM Companhia de Pesquisa em Recursos Minerais, 600 p.

CORRÊA, N. F. Obtenção de MDE corrigido para delimitação de bacia hidrográfica com auxílio de geotecnologias livres e gratuitas. Trabalho de Conclusão de Curso. Universidade Estadual de Mato Grosso do Sul. Dourados, 2015.

EARTH EXPLORER. Imagens Landsat 8. 2016. Disponível em: <http:// earthexplorer.usgs.gov/>.

EMBRAPA. Centro Nacional de Pesquisa de Solos (Rio de Janeiro, RJ). Sistema brasileiro de classificação de solos. 3. ed. - Rio de Janeiro: EMBRAPA-SPI, 2013, 306p.

ESRI INC. - ARC / INFO version 7.11. Environmental Systems Research Institute Inc. New York, 1997, 1 CD ROM.

IBGE - Instituto Brasileiro de Geografia e Estatistica, 2013. Disponivel em: <http://www.ibge.gov.br/home/geociencias/.htm>

OLIVEIRA, J.S. Avaliação de modelos de elevação na estimativa de perda de solos em ambiente SIG. 2012, Dissertação de Mestrado, Universidade de São Paulo, Escola Superior de Agricultura Luiz de Queiroz 103p.

OLIVEIRA, P.T.S.; RODRIGUES, D.B.B.; ALVES SOBRINHO, T.; CARVALHO, D.F.; PANACHUKI, E. Spatial variability of the rainfall erosive potential in the state of Mato Grosso do Sul, Brazil. Revista Engenharia Agrícola, v. 32, n. 1, p. 69-79, 2012.

PARANHOS FILHO, A. C.; OLIVEIRA, E. F.; MIOTO, C.L. BARBOSA, A. F.; Aplicação da Equação Universal de Perda do Solo (USLE) em Softwares Livres e Gratuitos. Anuário do Instituto de Geociências - UFRJ. v. 38, n. 1, p. 170-179, 2015.

PARANHOS FILHO, A.C. Análise geo-ambiental multitemporal: o estudo de caso da região de Coxim e da Bacia do Taquarizinho (MS - Brasil). 2000, Tese de Doutorado, Universidade Federal do Paraná, 213p.

QGIS DEVELOPMENT TEAM. QuantumGIS 2.8.8, 2015. Disponível em: <http:// www.qgis.org/en/site/>.

SANTOS, C.N. EI Niño, La Niña e a erosividade das chuvas no Estado do Rio Grande do Sul. Universidade Federal de Pelotas, Faculdade de Agronomia Eliseu Maciel, Programa de Pós-Graduação em Agronomia, 2008.

SILVA, M. L. N.; CURI, N.; MARQUES, J. J. G. S. M.; LIMA, L. A.; FERREIRA, M. M. Resistência ao Salpico Provocado por Impacto de Gotas de Chuva Simulada em Latossolos e sua Relação com Características Químicas e Mineralógicas. Ciência e Prática, Lavras, v. 19, n.2, p. 176-182, 1995.

SOARES FILHO; COMUNELLO, E. ; SOARES, J. S. . Caracterização Espaço-Temporal do Uso do Solo na Microbacia Hidrográfica do Córrego Laranja Doce, Sul de Mato Grosso Do Sul. SIMPÓSIO BRASILEIRO DE GEOGRAFIA FÍSICA APLICADA, 13. Viçosa, 2009, Anais...

SPATTI JUNIOR, E. Avaliação Ambiental, Caracterização da Qualidade de Água e Transporte de Sedimentos na Bacia Hidrográfica do Ribeirão Monjolo Grande (SP), 2011. Disertação de Mestrado, Universidade Estadual Paulista, Rio Claro. 
STEIN, D.P.; DONZELLI, P.; GIMENEZ, A.F.; PONÇANO, W.L.; LOMBARDI NETO, F. 1987. Potencial de erosão laminar natural e antrópica na bacia do Peixe-Paranapanema. In: SIMPÓSIO NACIONAL DE CONTROLE DE EROSÃO, 4, Marília, 1987. Anais... Marília, p. $105-135$.

USGS, United States Geological Survey. Shuttle Radar Topography Mission (SRTM), Global Land Cover Facility, University of Maryland, College Park, Maryland, 2000. WISCHMEIER, W.H.; SMITH, D.D. 1978. Predicting rainfall erosion losses; a guide to conservation planning. Washington: U.S. Department of Agriculture, (Agriculture Handbook n. 537), 58p. 